\title{
Application of sustainability indicators, soil organic matter and electrical conductivity, to resource management in the northern grains region
}



 \\ ${ }^{B}$ Department of Primary Industries, Animal Research Institute, Yeerongpilly, Qld 4105, Australia. \\ ${ }^{\mathrm{C}}$ Author for correspondence; e-mail:Ram.Dalal@nrm.qld.gov.au
}

\begin{abstract}
Sustainability is a multifaceted concept. It is expressed here as 'to ensure that the past and current management and use of natural resources does not diminish their capacity to meet economic, environmental, social and aesthetic needs and opportunities of the present and future generations'. Sustainability indicators can be used to monitor responses in condition and trend as a result of natural resource management. We report here 2 case studies that demonstrate the significance of sustainability indicators in discerning trends in land and water resources in the southern Brigalow (Acacia harpophylla) Belt, a major region of the Queensland Murray-Darling Basin. First, soil organic matter was used as a sustainability indicator of soil productivity, soil aggregation, and its association with soil sodicity since these soil attributes affect infiltration rates, runoff and drainage. The second study involved comparing the trends in stream salinity (electrical conductivity) over 35 years and sustainability indicators for a dominant Vertosol in a region used for cereal cropping. Groundwater level and electrical conductivity of a long-term monitoring bore in the Dalby-Chinchilla region, were also analysed to discern trends in salinity and association of the groundwater with soil and stream salinity.

Soil organic matter declined exponentially as the cultivation period for cereal cropping increased. This resulted in a reduction in soil nitrogen supply, and lower grain protein and cereal grain yields. The associated effects were reduced soil aggregation and increased soil sodicity. Electrical conductivity of the soil as well as stream water showed weak but declining trends with time. Groundwater level from the long-term monitoring bore near the stream and groundwater salinity showed significantly declining trends over the 35 years sampling period. Groundwater salinity was similar to the Vertosol electrical conductivity at $240-300 \mathrm{~cm}$ depths, suggesting groundwater connectivity to the overlaying soil. Thus, use of sustainability indicators provided a strong association among the various attributes of the landscape. However, it is still a challenge to integrate the various sustainability indicators in a landscape context, integrated over space (spatial and geographical distribution), attributes (quality characteristics) and time (trend).
\end{abstract}

Additional keywords: soil organic matter, electrical conductivity, stream salinity, groundwater salinity, aggregation, sodicity.

\section{Introduction}

Sustainability is a multifaceted concept. Therefore, it is not surprising that its meaning is ambiguous. It is expressed here as 'to ensure that the past and current management and use of natural resources does not diminish their capacity to meet economic, environmental, social and aesthetic needs and opportunities of the present and future generations'. The idea of sustainability indicators seems to recognise that sustainability cannot be precisely defined (Pannell and Schilizzi 2000) although it is increasingly being used for monitoring of natural resource use so that appropriate management practices are employed. Indicators are a composite set of measurable attributes which are derived from functional relationships and can be monitored via field observation, field sampling, remote sensing, survey or compilation of existing information (Walker and Reuter 1996). Indicators signal desirable or undesirable changes in land, water and vegetation management that have occurred or may occur in the future. By measuring key attributes of a system over time, indicators show the condition and trend of the resource being used (Walker and Reuter 1996; Dalal et al. 1999; Sparrow et al. 2000).

Sustainability indicators should meet the following criteria: respond to change in management practice and provide trends over time; be easily measured; have expected or threshold values; have low error associated with 
measurement; be stable in the short term to enable measurement; not be required to be frequently measured; be cost-effective; have the ability to be aggregated from paddock or site to farm/catchment region; be mappable in space and time; and have community acceptance and involvement. These indicators can be broadly grouped under resource maintenance/enhancement, biodiversity, productive capacity (e.g. yield, biomass production, input $v$. output efficiency), economic viability (disposable income), social acceptance (enhanced quality of life) and community and institutional structures (sustainable culture) (Dalal et al. 1999).

Detailed lists of sustainability indicators and their significance in monitoring the sustainability of resource use are available from Walker and Reuter (1996), Dalal et al. (1999), and others (Acton and Gregorich 1995; State of the Environment Advisory Council 1996; Karlen et al. 1997; Standing Committee on Agriculture and Resource Management 1998; Sparrow et al. 2000). Briefly, on-farm sustainability indicators of land resource use include $\mathrm{pH}$, electrical conductivity, adsorption capacity, organic matter and available nutrients, infiltration rate, aggregate stability, bulk density, rooting depth, surface crust and surface cover, microbial biomass, potentially mineralisable nitrogen, nematode groups, enzyme activity, fatty acid profiles and earthworms. The off-farm indicators include stream flow, stream turbidity, stream water $\mathrm{pH}$ and electrical conductivity (salinity), nutrients, pesticides, in-stream macroinvertebrates, riparian vegetation and sediments (Dalal et al. 1999), and groundwater level and salinity (Sparrow et al. 2000).

Sustainability indicators can be used for monitoring both the condition and trend of resource management (Walker and Reuter 1996). Examples of such studies in southern Australia include soil acidification under clover pasture (Williams 1980) and effects of subterranean clover pasture on soil fertility (Russell 1960; Watson 1969). Such studies in subtropical Australia are rare although trends in resource condition are likely due to increased temperature and rainfall variability, and hence increased biomass and water use or potential evapotranspiration.

We present here an application of sustainability indicators to resource management in the 2 case studies. These studies focused on monitoring trends in soil organic matter in a Vertosol and salinity in stream, groundwater and soil in the southern Brigalow (Acacia harpophylla) Belt, a major region in the Queensland Murray-Darling Basin.

\section{Soil organic matter}

Organic matter is fundamental to the maintenance of soil health (the capacity of a specific type of soil to function, within natural or managed ecosystem boundaries, to sustain plant and animal productivity, maintain or enhance water and air health, and support human health and habitation) because it is essential to the optimal functioning of a number of processes important to sustainable ecosystems (Acton and
Gregorich 1995; Karlen et al. 1997). Soil organic matter is a source and sink of carbon and nitrogen and partly of phosphorus and sulfur. It affects micronutrient availability through complexation, chelation and production of organic acids, thus altering soil $\mathrm{pH}$. Conversely, it ties up metals present in toxic amounts (e.g. $\mathrm{Cu}, \mathrm{As}, \mathrm{Hg}$ ) (Doran and Parkin 1996).

Organic matter is essential for good soil structure, especially in low clay content soils, as it contributes towards both formation and stabilisation of soil aggregates (Dalal and Bridge 1996). Other functions include: contribution to cation exchange capacity, especially in low activity clay and low clay content soils, pesticide retention (Kookana et al. 1998), microbial biodiversity, water retention in sandy and sandy-loam soils, and provision of a carbon sink and source for greenhouse gases (Dalal and Carter 2000). Trends in soil organic matter content provide an integrated measure of the biophysical component of sustainable ecosystems (Karlen et al. 1997).

\section{Electrical conductivity (a measure of salinity)}

Electrical conductivity is a measure of salt concentration and can, therefore, provide trends in soil and water salinity, limitations to crop growth and water infiltration. Soil electrical conductivity and $\mathrm{pH}$ (indicating soil sodicity) can be a surrogate measure of soil structural decline (Rengasamy and Olsson 1991), and landscape salinity (Hatton 1999). Electrical conductivity affects water infiltration rates. Soil water infiltration measures the rate at which water enters the soil surface, and is transmitted through the immediate soil depth (Arshad et al. 1996). Rainfall is rapidly absorbed by soil with a high infiltration rate, but as the soil structure deteriorates, usually with the loss of organic matter, increase in exchangeable sodium and low electrolyte concentration (low salinity), the infiltration rate of a soil becomes low (Rengasamy and Olsson 1991). This increases the tendency for soil erosion and runoff in sloping soils and waterlogging in flat soils, thus affecting stream salinity. It also affects the water recharge to groundwater and groundwater salinity.

\section{Methods}

Soil monitoring for organic matter and electrical conductivity

Soil organic matter, electrical conductivity, aggregation and exchangeable sodium percentage measurements were made on Langlands-Logie soil (Vertosol) in the Dalby-Chinchilla area, southern Brigalow Belt, by the following 2 approaches. In the first approach, the paired-site sampling approach, soil samples were collected, generally during April-July, from farmers' fields that had been under cultivation for 0.5-45 years (calendar years 1935-1980), and from an adjacent area that had never been cultivated. The details of this methodology are given by Dalal and Mayer (1986a).

In the second approach, the oldest cultivated field (used for cereal cropping since 1935) on a Langlands-Logie soil was used to conduct a field experiment from 1985 to 1998. Soil organic matter and electrical conductivity were measured regularly during this period. The experimental details and soil organic matter content up to 1994 are given by Dalal et al. (1995). In May 2000, the field was again sampled 
to $3 \mathrm{~m}$ depth from the continuous cereal cropping area, the cultivated area that has carried pasture for the last 15 years, and the adjoining area carrying native vegetation (Acacia harpophylla).

The soil sampling procedure, soil processing and analytical techniques, and statistical analysis of the data are described in detail by Dalal and Mayer (1986a, 1986b) and Dalal et al. (1995).

Data on the volumes of stream water and stream water electrical conductivity were obtained from the HYDSYS database held at NR\&M, Indooroopilly (NRM 2001). Electrical conductivity was measured by standard techniques (Franson 1992). Trends in annual discharge and electrical conductivity were determined after accounting for climate signals (regional rainfall, Southern Oscillation Index, and Decadal Pacific Oscillation) in stepwise multiple regression analysis, and then analysing the residuals against time (since stream discharge with time showed no trend, it was not considered further in this study). Since stream water electrical conductivity showed no significant relationship to climate signals, the trend was analysed by analysing for linear regression against time. Where required, these variables were natural log-transformed before analysis, to approximately stabilise variances. Where monthly data were available, time series and seasonality models were investigated, and fitted before the overall time trend being tested.

The data for groundwater level and conductivity were obtained from the Groundwater Data Base held at NRM, Indooroopilly. Trends in groundwater level and groundwater electrical conductivity were analysed in a similar way to analysis of stream water data. The data for the monitoring bore $\mathrm{RN}$ 42230156, as a typical representative of 30 long-term monitoring bores in the Dalby-Chinchilla area, are presented in this paper.

\section{Results and discussion}

Soil organic matter

Soil organic $\mathrm{C}$ concentration declined exponentially with increasing period of cultivation (Fig. 1), with a net rate of loss of $0.06 \% / \%$ per year (Dalal and Mayer 1986b). This trend was confirmed further by repeated sampling in 1 location for almost 15 years (Dalal et al. 1995).

Since organic C loss was closely associated with total N loss for this soil, Dalal et al. (1991) showed that wheat grain protein levels also declined as the soil organic matter $(\mathrm{C}$ and $\mathrm{N})$ declined in this Vertosol. Moreover, soil aggregation $(>20 \mu \mathrm{m})$ decreased at a rate of -0.025 per year as the period of cereal cropping increased (Dalal et al. 1991), and was thus at least partly associated with the decreasing amount of organic matter in soil. Tisdall and Oades (1982) also showed a close relationship between soil aggregation and organic matter concentration in a number of soils.

The significant inverse relationship between soil organic matter and exchangeable sodium percentage (ESP) (Fig. 2) $(P<0.01)$ in this Vertosol, which in turn affects soil aggregation (Rengasamy and Olsson 1991), emphasises the integral nature of soil organic matter as a sustainability indicator for monitoring the condition and trend of land resource (Karlen et al. 1997). As the soil organic matter declines and exchangeable sodium percentage increases in the surface layer, aggregation decreases, and as a result infiltration rate and hydraulic conductivity also decrease (Cook et al. 1992), resulting in increasing runoff from these soils.

\section{Soil electrical conductivity (a measure of soil salinity)}

Soil electrical conductivity showed a weak $(P=0.056)$ but declining trend with the period of cultivation (Fig. 3). After 49-65 years of cereal cropping, electrical conductivity was significantly reduced down to $270 \mathrm{~cm}$ depth as compared to the soil under native vegetation (Table 1). This was primarily due to increased water movement downward, hence salt movement downward in the soil profile. Dalal (1986) estimated that almost $750 \mathrm{~kg} /$ ha.year sodium chloride equivalent salts moved below $120 \mathrm{~cm}$ depth in this Vertosol over an 18-year period. However, the increasing use of water by the grass + legume pasture (Setaria incrassata, Chloris gayana, Medicago sativa, M. truncatula and M. scutellata)



Figure 1. Decrease in soil organic carbon content (\%) with increasing period of cereal cropping in the Chinchilla region, Queensland, southern Brigalow Belt. The equation of the line is: $y=0.64+1.62 \exp (-0.06 x) ; R^{2}=0.90, P<0.05$ (adapted from Dalal and Mayer 1986). 


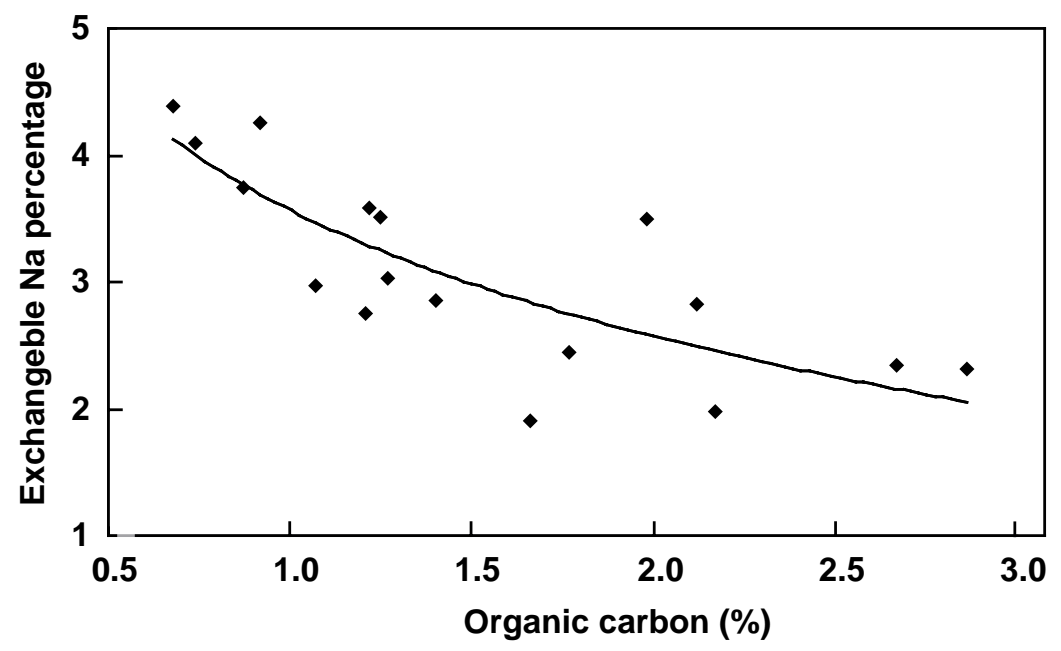

Figure 2. Relationship between ESP and organic C in a Vertosol near Chinchilla, Queensland, southern Brigalow Belt. The equation of the line is: $y=3.57-1.44 \ln x ; R^{2}=0.64, P<0.05$

(data from Dalal and Mayer 1986a, 1986b).

reduced the downward movement of water in the top $120 \mathrm{~cm}$ depth, where pasture roots would be most active.

\section{Stream water electrical conductivity (as a measure of stream} water salinity)

Stream water electrical conductivity of the Condamine River at Chinchilla fluctuated from 100 to $950 \mu \mathrm{S} / \mathrm{cm}$, with a mean value of $430 \mu \mathrm{S} / \mathrm{cm}$ over the last 35 years of the monitoring period (Fig. 4). There was a strong seasonal pattern $\left(R^{2}=0.27, N=82\right)$ and a significant $(P<0.05)$ decline over time (regression coefficient $=-4.19 \pm 1.69 \mu \mathrm{S} / \mathrm{cm}$.year; $P<0.05$ ) (full model, $R^{2}=0.32$ ). Also, it was strongly associated with total suspended solids in stream water $\left(R^{2}=0.51, N=64\right)$.
Stream water electrical conductivity declined by $4.2 \mu \mathrm{S} / \mathrm{cm}$.year during the 35 -year period of monitoring. The stream water discharge as the covariate did not improve the electrical conductivity-year relationship. McNeil and Horn (1997) also found a poor or declining trend in stream water electrical conductivity at a number of monitoring stations on the Condamine River. Considering that the electrical conductivity of the soil $(0-10 \mathrm{~cm})$ decreases or approaches steady state as the period of cultivation increases (Fig. 3), runoff from these older soils, which are likely to contain less salts in the top layer, a steady or declining trend in stream water electrical conductivity is expected, especially when annual stream discharge is also steady (data not presented).

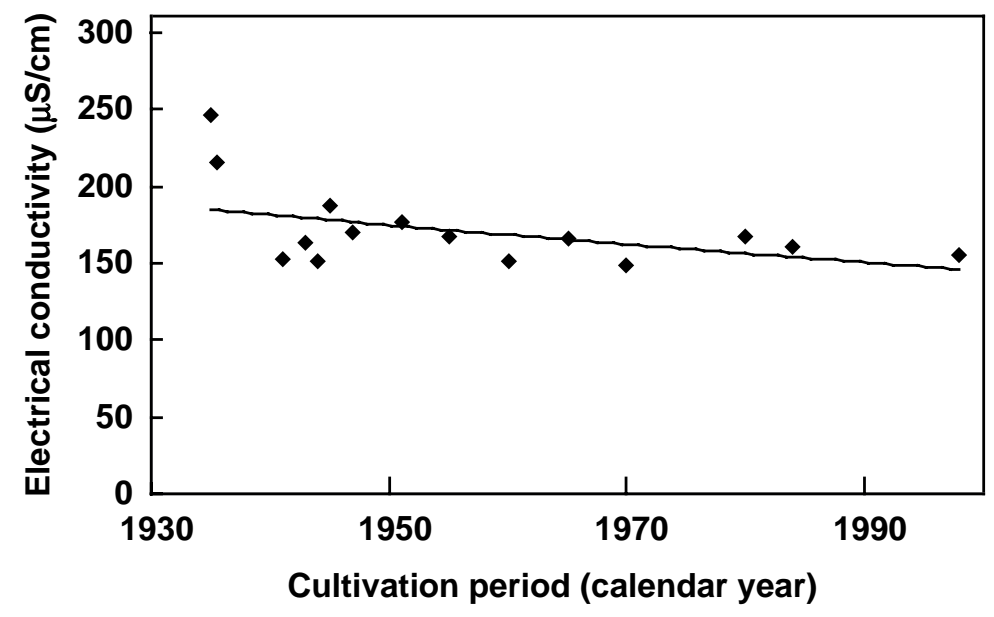

Figure 3. Trends in electrical conductivity of a Vertosol $(0-10 \mathrm{~cm}$ depth) near Chinchilla, Queensland, southern Brigalow Belt. The equation of the line is:

(R. C. Dalal unpublished data).

$$
y=250196 \exp (-0.0037 x) ; R^{2}=0.25, P=0.056
$$




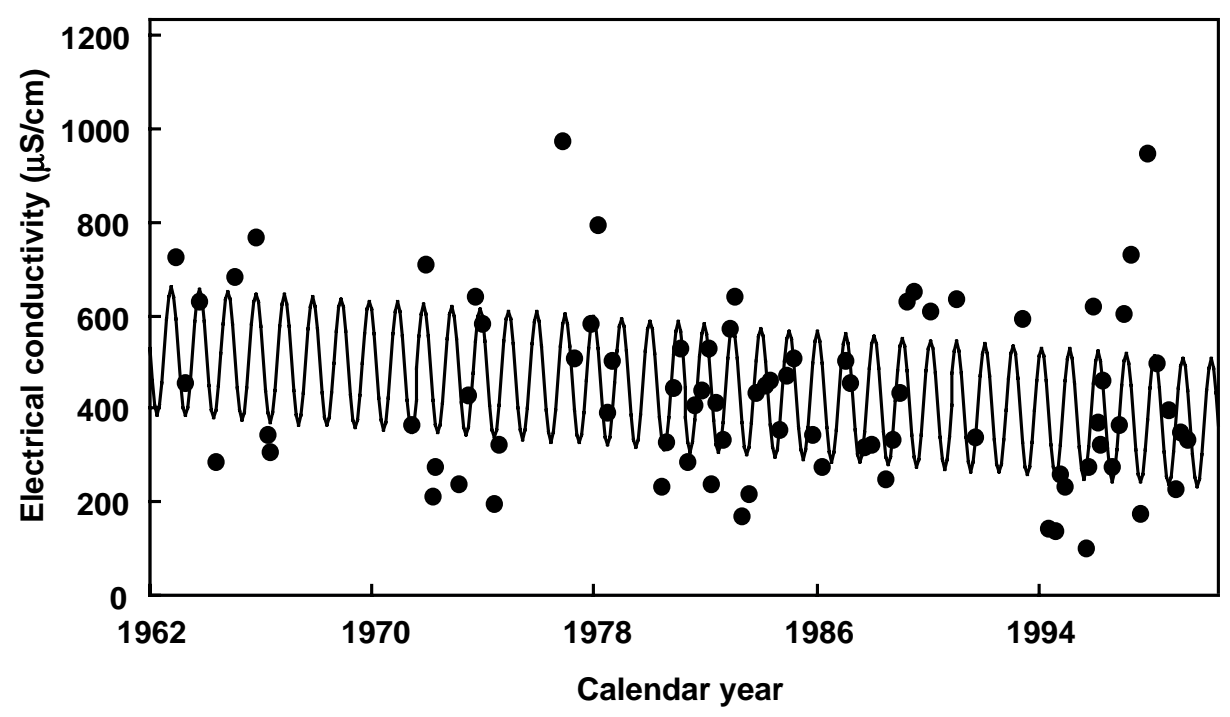

Figure 4. Trends in stream water electrical conductivity (as a measure of salinity) of the Condamine River at Chinchilla, Queensland, southern Brigalow Belt. The equation of the line is: $y=8747-4.19 x-137 \sin [2 \pi(x-1962)] ; R^{2}=0.32 ; P<0.01$.

Groundwater levels in the Dalby-Chinchilla region, especially in the agriculturally developed areas where monitoring bores are located, generally showed a significantly declining trend with time (Fig. 5). Of the 30 monitoring bores, groundwater level decreased in 24 bores and was stable in 3 bores; only in 3 bores the groundwater level showed increasing trend (data not presented). As expected, there was also a cyclic trend in groundwater level during this period (Fig. 5), possibly coinciding with rainfall trends. Over a 35-year period, groundwater level declined by $5.5 \mathrm{~m}$, at an average rate of $156 \mathrm{~mm}$ per year. McNeil and Horn (1997) also reported a

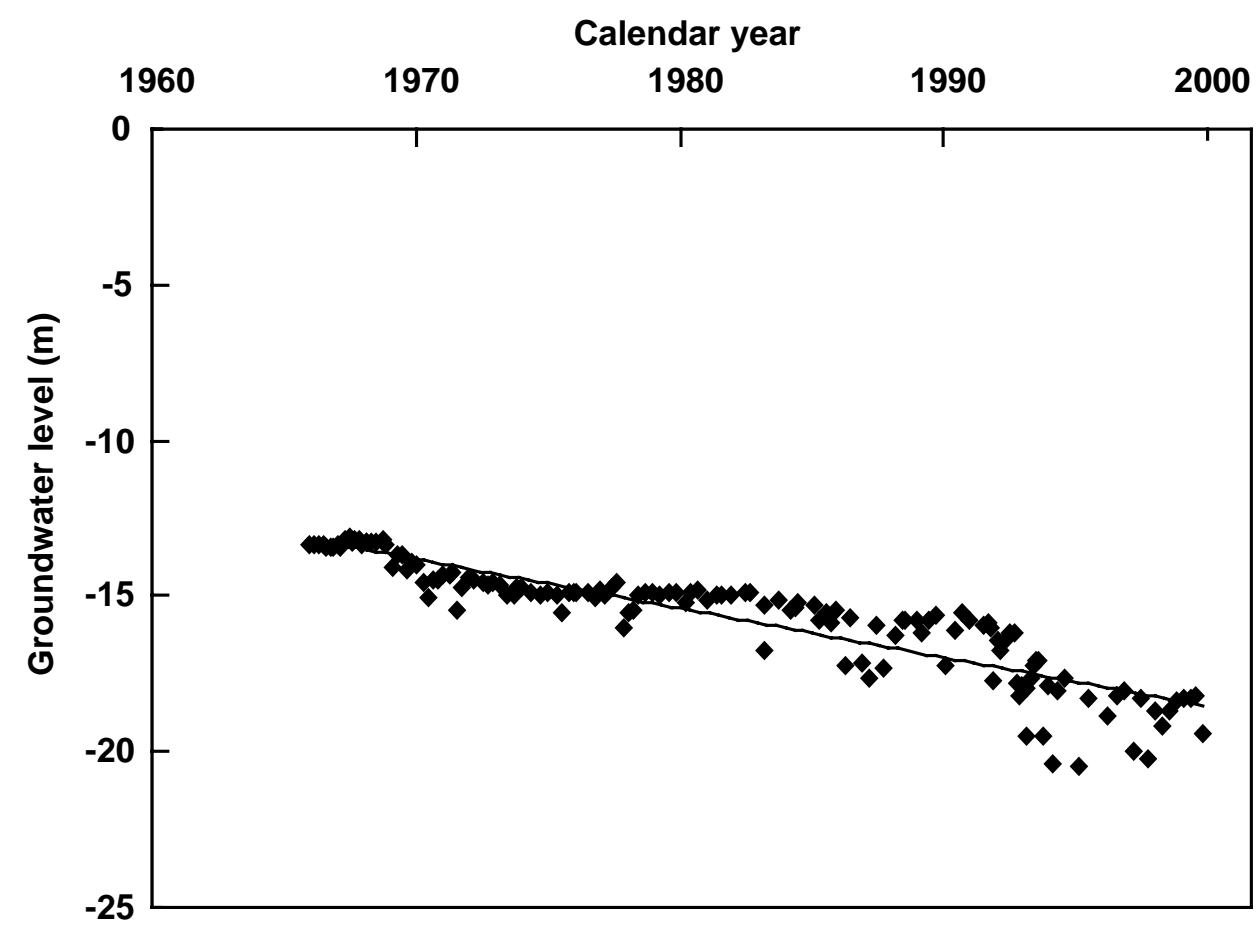

Figure 5. Trends in groundwater level of a monitoring bore ( $\mathrm{RN}$ 42230156) near Chinchilla, Queensland, southern Brigalow Belt. The equation of the line is:

$$
y=-4.986 \times 10^{-8} \exp (0.00987 x) ; R^{2}=0.85, P<0.001 \text {. }
$$




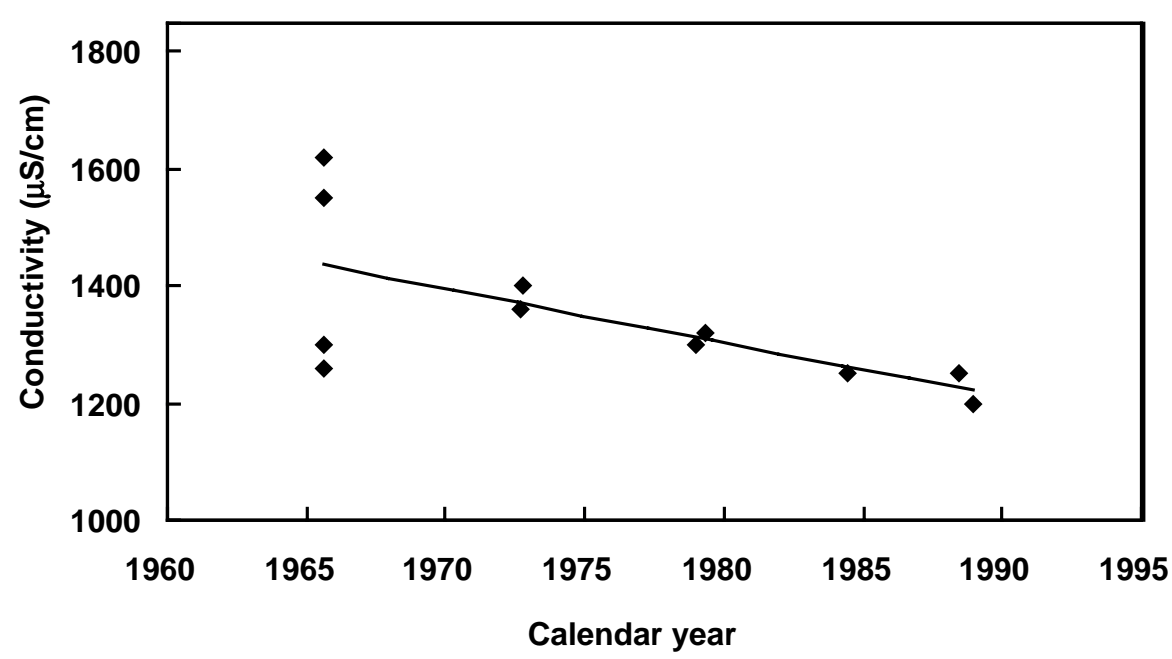

Figure 6. Trends in electrical conductivity of a groundwater monitoring bore (RN42230156) near Chinchilla, southern Brigalow Belt. The equation of the line is: $y=19465-9.17 x ; R^{2}=0.42, P<0.05$.

general fall in groundwater levels in this region during the 1980-1992 period. The groundwater level trend indicates the balance between water usage, recharge, storage and natural discharge (McNeil and Horn 1997; Hatton 1999). Apparently, water usage, mostly for irrigation, and natural discharge exceeded the water recharge during the monitoring period. There may also have been an increase in runoff due to increasing exchangeable sodium percentage and decreasing soil aggregation although stream water discharge did not show increasing trend (data not presented), possibly due to increased stream water use and surface storage during this period.

Although electrical conductivity measurements were fewer than the groundwater level data, the electrical conductivity of groundwater of the monitoring bore also showed a declining trend (Fig. 6). Considering the fact that the electrical conductivity values of the groundwater were similar to those of the Vertosol layers in $240-300 \mathrm{~cm}$ depths or below (Table 1), it is most likely that the water recharge occurred from drainage above in this floodplain.

These 2 case studies demonstrate the significance of using sustainability indicators in long-term monitoring of a landscape for soil organic matter, and soil, stream and groundwater salinity to discern trends in resource condition, and evaluate the interrelationship of the attributes monitored as well as taking into account the variable climatic effects, which complicate the trend analysis from short-term monitoring of resources in this environment.

\section{Conclusions}

The significance of the sustainability indicators (soil organic matter and electrical conductivity of land, and stream and groundwater) becomes apparent as the period of monitoring increases since climate variability is important in evaluation of the condition and trend of natural resources being used. It is still a challenge to integrate the various

Table 1. Electrical conductivity $(\mu \mathrm{S} / \mathrm{cm})$ of a Vertosol near Chinchilla, Queensland, southern Brigalow Belt under native vegetation (Acacia harpophylla), cultivation for cereal cropping and crop-pasture land use

\begin{tabular}{lccccc}
\hline $\begin{array}{l}\text { Soil depth } \\
(\mathrm{cm})\end{array}$ & $\begin{array}{c}\text { Native } \\
\text { vegetation }\end{array}$ & $\begin{array}{c}\text { Cropping for } \\
49 \text { years }\end{array}$ & $\begin{array}{c}\text { Cropping for } \\
65 \text { years }\end{array}$ & $\begin{array}{c}\text { Cropping for 49 years } \\
+ \text { pasture 15 years }\end{array}$ & $\begin{array}{c}\text { l.s.d. } \\
(P=0.05)\end{array}$ \\
\hline $0-30$ & 416 & 188 & 242 & 231 & 95 \\
$30-60$ & 1155 & 364 & 453 & 457 & 147 \\
$60-90$ & 1378 & 683 & 509 & 964 & 176 \\
$90-120$ & 1504 & 992 & 777 & 1176 & 139 \\
$120-150$ & 1542 & 1263 & 1015 & 1264 & 151 \\
$150-180$ & 1580 & 1382 & 1163 & 1383 & 205 \\
$180-210$ & 1580 & 1370 & 1238 & 1443 & 202 \\
$210-240$ & 1676 & 1355 & 1356 & 1484 & 189 \\
$240-270$ & 1684 & 1411 & 1565 & 1676 & 166 \\
$270-300$ & 1722 & 1442 & 1676 & 1820 & 127 \\
\hline
\end{tabular}


sustainability indicators in integrated resource management (Walker and Reuter 1996). A way forward would be to benchmark the optimum threshold values for soil, land and water quality using the sustainability indicators and then determining the extent of deviation from the benchmark values in a given landscape or environment. These values then could be integrated over space (spatial and geographical distribution), attributes (quality characteristics) and time (trend) to produce the condition and trend of natural resource use. Target values can be set and remedial action taken to meet the standards stipulated by ANZECC and the Standing Committee on Agriculture and Resource Management (1998).

\section{Acknowledgments}

We thank Ms K. Page for providing soil electrical conductivity data, $\mathrm{Mr} \mathrm{C}$. Chin for climate analysis, and the staff of database management (G. Dawson, P. Kelley and P. Fiedler) for providing the stream water and groundwater data. We also thank the 2 anonymous reviewers for their suggestions.

\section{References}

Acton DF, Gregorich LJ (1995) The health of our soils - towards sustainable agriculture in Canada. Centre for Land and Biological Resources Research, Research Branch, Agriculture and Agri-Food Canada, Ottawa.

Arshad MA, Lowery B, Grossman B (1996) Physical tests for monitoring soil quality. In 'Methods for assessing soil quality'. (Eds JW Doran, AJ Jones) pp. 123-141. Special Publication No. 49. (SSSA: Madison, USA)

Cook GD, So HB, Dalal RC (1992) Structural degradation of Vertisols under continuous cultivation. Soil and Tillage Research 22, 47-64.

Dalal RC (1986) Salinity trends in Brigalow soils. In 'Landscape, Soil and water salinity, proceedings of the Darling Downs regional workshop', Toowoomba, March 1986. pp. B5-1-B5-5. QDPI Publication QC 86001.

Dalal RC, Bridge BJ (1996) Aggregation and organic carbon storage in sub-humid and semi-arid soils. In 'Advances in soil science'. (Eds MR Carter, BA Stewart) pp. 263-307. (CRC Press Inc.: New York)

Dalal RC, Carter JO (2000) Soil organic matter dynamics and carbon sequestration in Australian tropical soils. In 'Global climate change and tropical soils: advances in soil science'. (Eds R Lal, JM Kimble, BA Stewart) pp. 283-314. (CRC Press Inc.: New York)

Dalal RC, Mayer RJ (1986a) Long-term trends in fertility of soils under continuous cultivation and cereal cropping in southern Queensland. 1. Overall changes in soil properties and trends in winter cereal yields. Australian Journal of Soil Research 24, 265-279.

Dalal RC, Mayer RJ (1986b) Long-term trends in fertility of soils under continuous cultivation and cereal cropping in southern Queensland. 2. Total organic carbon and its rate of loss from the soil profile. Australian Journal of Soil Research 24, 281-292.

Dalal RC, Lawrence P, Walker J, Shaw RJ, Lawrence G, Yule D, Doughton JA, Bourne A, Duivenvoorden L, Choy S, Moloney D, Turner L, King C, Dale A (1999) A framework to monitor sustainability in the grains industry. Australian Journal of Experimental Agriculture 39, 605-620.
Dalal RC, Strong WM, Weston EJ, Cooper JE, Lehane KJ, King AJ, Chicken CJ (1995) Sustaining productivity of a Vertosol at Warra, Queensland, with fertilisers, no-till or legumes. 1. Organic matter status. Australian Journal of Experimental Agriculture 37, 903-913.

Dalal RC, Strong WM, Weston EJ, Gaffney J (1991) Sustaining multiple production systems. 2. Soil fertility decline and restoration of cropping lands in subtropical Queensland. Tropical Grasslands 25, 173-180.

Doran JW, Parkin TB (1996) Quantitative indicators of soil quality: A minimum data set. In 'Methods for assessing soil quality'. (Eds JW Doran, AJ Jones) pp. 25-37. Special Publication Number 49. (SSSA: Madison)

Franson MAH (1992) 'Standard methods for the examination of water and wastewater (17th edn).' (American Water Works Association, American Public Health Association and Water Pollution Control Federation: Washington DC)

Hatton T (1999) Salinity: a natural model - learning from natural ecosystems in saline environments. Natural Resource Management 2, 9-13.

Karlen DL, Mausbach MJ, Doran JW, Cline RG, Harris RF, Schuman GE (1997) Soil quality: a concept, definition and framework for evaluation. Soil Science Society of America Journal 61, 4-10.

Kookana RS, Baskaran S, Naidu R (1998) Pesticide fate and behaviour in Australian soils in relation to contamination and management of soil and water: a review. Australian Journal of Soil Research 36, 715-764.

McNeil VH, Horn AM (1997) Groundwater salinity trends in the northern Murray-Darling Basin. In 'Groundwater in the balance'. (Ed. L Foster) pp. 115-124. (Department of Natural Resources: Brisbane, Qld)

NRM (2001) Department of Natural Resources and Mines, Hydrology Database, Indooroopilly, Qld.

Pannell DJ, Schilizzi S (2000) Sustainable agriculture: a question of ecology, equity, economic efficiency or expediency? Journal of Sustainable Agriculture 13, 57-66.

Rengasamy P, Olsson KA (1991) Sodicity and soil structure. Australian Journal of Soil Research 29, 935-952.

Russell JS (1960) Soil fertility changes in the long-term experimental plots at Kybybolite, South Australia. 1. Changes in $\mathrm{pH}$, total nitrogen, organic carbon and bulk density. Australian Journal of Agricultural Research 11, 902-926.

Sparrow LA, Sharpley AN, Reuter DJ (2000) Safeguarding soil and water quality. Communications in Soil Science and Plant Analysis 31, 1717-1742.

Standing Committee on Agriculture and Resource Management (1998) Sustainable Agriculture: assessing Australia's recent performance. A Report to SCARM of the National Collaborative Project on Indicators for Sustainable Agriculture. SCARM Technical Report 70. (CSIRO Publishing: Melbourne)

State of the Environment Advisory Council (1996) 'Australia, state of the environment 1996.' (CSIRO Publishing: Melbourne)

Tisdall JM, Oades JM (1982) Organic matter and water-stable aggregates in soils. Journal of Soil Science 33, 141-163.

Walker J, Reuter DG (1996) 'Indicators of catchment health: a technical perspective.' (CSIRO Publishing: Melbourne)

Watson ER (1969) The influence of subterranean clover pastures on soil fertility. 3. The effect of applied phosphorus and sulfur. Australian Journal of Agricultural Research 20, 447-456.

Williams CH (1980) Soil acidification under clover pasture. Australian Journal of Experimental Agriculture and Animal Husbandry 20, 561-567.

Received 24 November 2000, accepted 3 August 2001 